\title{
Foreign Direct Investment and Youth Employment Causality: Evidence From ASEAN-5 Countries
}

\author{
Axellina Muara Setyanti ${ }^{1^{*}}$, Setyo Tri Wahyudi ${ }^{2}$ \\ ${ }^{12}$ Department of Economics, Faculty of Economics and Business, Brawijaya University, Indonesia \\ 1axellinamuara@ub.ac.id, ${ }^{2}$ setyo.tw@ub.ac.id \\ *corresponding author
}

\begin{abstract}
FDI - employment relationship has been a major concern of many researchers due to it's various findings. FDI is stated that able to trigger growth in employment, however, on the other hand, some have found that employment conditions affect FDI inflow. Meanwhile, several studies found a bidirectional relationship, or even no-relationship. With a focus on youth employment, this study aimed to examine the link between FDI and youth employment in ASEAN-5 countries. From the results of the Granger Causality test, it was found that in Indonesia, Malaysia, Philippines, and Singapore the FDI inflow is leading to youth employment, while in Thailand, the relationship is vice versa. Overall, there is no bidirectional causal relationship between FDI and youth employment in ASEAN-5 countries.
\end{abstract}

Keywords: Foreign Direct Investment, Youth Employment, Granger Causality, ASEAN-5

\section{Kausalitas Penanaman Modal Asing dan Penyerapan Tenaga Kerja Muda: Bukti dari Negara-negara ASEAN-5}

\begin{abstract}
Abstrak
Keterkaitan antara FDI dan penyerapan tenaga kerja telah menjadi perhatian utama banyak peneliti karena temuan yang beragam. FDI dinyatakan dapat memicu pertumbuhan lapangan kerja, namun di sisi lain, beberapa peneliti menemukan bahwa kondisi ketenagakerjaanlah yang mempengaruhi arus masuk FDI. Sementara itu, beberapa penelitian lain menemukan adanya hubungan dua arah, atau bahkan tidak ada hubungan. Dengan fokus pada penyerapan tenaga kerja muda, penelitian ini bertujuan untuk mengkaji hubungan antara FDI dan penyerapan tenaga kerja muda di negara-negara ASEAN-5. Dari hasil uji kausalitas Granger ditemukan bahwa di Indonesia, Malaysia, Filipina, dan Singapura, aliran FDI yang masuk mengarah pada pada penciptaan lapangan kerja bagi kaum muda, sedangkan di Thailand ditemukan hubungan yang sebaliknya. Secara keseluruhan, tidak ditemukan hubungan kausal dua arah antara FDI dan penyerapan tenaga kerja muda di negara-negara ASEAN-5.
\end{abstract}

Kata kunci: Penanaman Modal Asing, Penyerapan Tenaga Kerja Muda, Kausalitas Granger, ASEAN-5

\section{INTRODUCTION}

International businesses and foreign direct investments (FDI) are consequences in a modern global economy. These two play a significant role for a country, especially for the host. Foreign Direct Investment could be a key driver for the host country's economic development and rose the impact on the labour market. World Investment Report 2018 taking notes that the number of employment created all around the world due to FDI was reaching 73.2 million in 2017 and it was significantly increased by $171 \%$ since the 1990s (UNCTAD, 2018). Thus Foreign Direct Investments (FDI) has become certain attention of many recent studies, regarding the impact on job creation. According to ILO (2020), the global youth unemployment rate was $13.6 \%$ of the youth labour force in 2019 and is 
likely to increase by $0.1 \%$ in 2020 and continued to increase by $0.1 \%$ in 2021 . Thus, FDI is expected to make job creation in the host country especially for youth.

From the macroeconomics perspective, youth employment, of people aged 15-24 years, is beneficial to both the business firm growth, as well as to community and national growth. In addition to the abundance number in some countries, the youth are energetic, courageous and full of new ideas, they can bring social-economic changes and development as long as there are opportunities and they got involved in economic activities of the country (Msigwa \& Kipesha, 2013). Although they lack of job experience, youth are fast learner and can cope easily with global changes, especially technology. They have good health which enables them to work for a longer time than the elder. They also have a longer return on the investment as they can work for longer period in the firms compared to elder employees (ILO, 2011). But, at the same time, the share of youth unemployment has been rising in many countries, although some policies may have been conducted by governments to look up better wellbeing for youth (Mkombe et al, 2020).

More than half of the population of ASEAN aged under 30 (IMF, 2018), meanwhile ASEAN is now including in the world's top five economies, behind the US, EU, China, and Japan with fast growth in the economic (PwC, 2018). ASEAN-5 countries: Indonesia, Malaysia, Philippines, Singapore, and Thailand, known as the original member of ASEAN, equate to a total of 486 million people, accounting for over $6 \%$ of the world's population with a GDP of US $\$ 2.75$ trillion growing at an average rate of $3,7 \%$ in 2019 . At the same period, the total FDI inflow reaching US\$151,8 billion (World Bank, 2020). ASEAN-5 countries could be distinctive destinations for international businesses when they are setting up an expansion to a broader market. Due to the population size, investors will look for a conducive investment climate and efficient business costs. ASEAN-5 markets as relatively favorable for these criteria. These countries also have an abundance of young and skilled labour ( $\mathrm{PwC}, 2018)$. It is also related to the fact that this decade, most of the Asian countries be up against the big share of youth population and the challenge to provide youth employment (Pieters, 2013).

In the literature, foreign direct investment (FDI) is often identified as the key driver to raise the employment rate, economic growth, and development in developing nations (Ernst, 2005; Jibir \& Abdu, 2017). There is an important theory about FDI, which is called The Eclectic Paradigm of International Production or is also known as the OLIModel or OLI-Framework. It is a further development of the internalization theory by (Dunning, 2003). According to the Eclectic Paradigm of International Production theory, labour could be a valuable resource of the host country that attracts FDI. If the host country does have an advantage in the labour, the multinational corporation will make full use of the labour source. It brings an increase in employment within the host country. Therefore, in this theory, there is a positive link between FDI and employment.

On the other hand, the employment condition of a country could be an attractive factor for FDI. High labour costs are believed to be a barrier to inward FDI. However, among major variables that measure a country's investment attractiveness, absolute labour cost does not always appear to be a determining factor and is not really considered in the 
investment decisions. Nonetheless, the variable cost may become a stronger consideration in certain industries, especially when the industry is labour-intensive (Ernst, 2005). The high cost of labour will discourage FDI inflows in a country. Labour with high cost will affect the effectiveness of investment due which will eventually degrade the return on investment (Karim et al, 2019). Investors will tend to make an investment that involves a combination of modern technology, having an openness to foreign trade, with a large supply of low-cost labour (Lipsey, 2006).

Besides increasing employment through the introduction of new industries and the establishment of new firms in the host country, inward FDI may establish linkages with domestic firms. Domestic firms could be the provider for goods and services required by foreign companies. It is also possible that there is a technological transfer to the domestic firms and their production process. This will make them more competitive and make a chance for them to expand in production and increase in employment (Karlsson et al, 2007). But contrarily, Karlsson et al (2007) also showed another side, that inward FDI might also decrease employment in domestic firms. This will happen if foreign firms are in one market arena with domestic firms and make a competition. If the foreign firms are more effective in production, they might force the domestic firms to exit the market or downsize their workforce. It could be imagined that such a crowding-out effect is important when foreign MNEs do not only focus on export markets but also target the domestic market.

There are several studies conducted to examine the link between FDI and employment in general. Some of them found that FDI leads to employment, such as Goel (2020) in India, Patel \& Choga (2018) in South Africa, and Tsaurai (2018) in BRICS countries. Previously, the research of Bakkalcı \& Argin (2013) in Turkey, Yayli \& Deger (2012) in some developing countries, Adam \& Zurek (2011) in Poland, and Karlsson et al (2007) in China. Most of the studies found that FDI creating jobs in the host country, or making a positive link. The positive link on job creation depends on the firm characteristics and peculiarly, their openness to export markets. There is also another finding of a positive indirect effect on job creation in domestically owned firms, the socalled spill-over effect (Karlsson et al, 2007). But some others that employment affecting FDI inflow. Parcon (2008) examined FDI inflows to a group of 195 countries in 19902005 and found that FDI links to labour market differently in developed and developing countries, specifically negative in some cases and positively in other cases regarding the labour market regulation. Among the many studies examining the relationship between FDI and employment, this study will look different with a focus on youth employment.

Finally, the link between inward FDI and employment will vary significantly among countries, associated with the country's structure of the economy and also on the type of inward FDI. It could also vary along different periods. Remarkably there is also the fact that in several studies being reported no relation between two phenomena. Notably, this research will focus on FDI - employment relationships for the host country, following the pattern from Erdal \& Tatoglu (2002) that influences of FDI on the employment and any other macroeconomics condition can be observed in the host country. 


\section{METHOD}

This study is attempted to examine the link between inward FDI and youth employment using the causality method in ASEAN-5 countries: Indonesia, Malaysia, Philippines, Singapore, and Thailand from 2000 to 2019. Ten years of observation period are considered because most of the ASEAN-5 countries have increasing FDI trend in the last decade. In this research, FDI meant by the net FDI inflow, measured in percentage of GDP. Meanwhile, youth employment refers to the proportion of the population ages 1524 that is economically active. It is also defined as all people who supply labour for the production of goods and services during a specified period. Estimation in this study will be carried out in two stages, namely the unit root test and causality testing using the Granger Causality approach.

\section{Unit Root Test}

Stationarity is one of the important prerequisites in the econometrics model using time series data. Stationary data is data that shows the mean and variance remains the same at any time the data is used, meaning that with stationary data the model with time series data can be said to be more stable. If the data used in the model is not stationary, then the validity and stability of the data are reconsidered.

\section{Granger Causality Test}

The Granger causality test is used to test the causality relationship between two variables in the regression, which in this case are FDI and youth employment. The basic Granger causality equation model is as follows:

$$
\begin{aligned}
& Y_{t}=\sum_{i=1}^{m} \alpha_{i} Y_{t-1}+\sum_{j=1}^{m} \beta_{j} X_{t-j}+v_{t} \\
& X_{t}=\sum_{i=1}^{m} \alpha_{i} X_{t-1}+\sum_{j=1}^{m} \beta_{j} Y_{t-j}+v_{t}
\end{aligned}
$$

Where:

Y : FDI

$\mathrm{X} \quad$ : Youth employment

$\mathrm{m} \quad$ : number of lag

$\alpha, \beta \quad$ : variables coefficient

$\mathrm{V} \quad$ : error term

There are four possible cases of this causality relationship, so that the following four hypotheses are formed:

H1: There is an unidirectional causality of FDI affecting Youth Employment

H2: There is an unidirectional causality of Youth Employment affecting FDI

H3: There is a bidirectional causality relationship, FDI and Youth Employment influence each other

H4: There is an independent relationship/no relationship between FDI and Youth Employment 
Jurnal Economia, 17(2), October 2021, 208-219

\section{FINDING AND DISCUSSION}

Firstly, all the data used in the previous causality test was carried out by unit root tests based on the 5 percent degree of confidence. The results of the unit root test by comparing the probability results with a critical value are as follows:

Table 1. Unit Root Test

\begin{tabular}{lcccc}
\hline \multirow{2}{*}{ Variables } & \multicolumn{2}{c}{ ADF Levin-Lin-Chu } & \multicolumn{2}{c}{ Breitung } \\
\cline { 2 - 5 } & Level & First Difference & Level & First Difference \\
\hline FDI & $0,0002^{*}$ & - & $0,0415^{*}$ & - \\
Youth & 0,2249 & $0,0000^{*}$ & 0,8819 & $0,0000^{*}$ \\
Employment & & & & \\
\hline
\end{tabular}

Note: *significant in 5\% degree of confidence

Source: Data estimation (2020)

From the test results above, it can be interpreted that the FDI variable is stationary at the level, while the youth employment variable is stationary at the first difference, both in the ADF Levin-Lin-Chu and Breitung approaches. Because all data have been stationary, it can be continued to test the causality. Next, in this research, Granger causality test of FDI and youth employment were used, where an exogenous variable can be treated as an endogenous variable. In identifying the causal relationship between the two variables, the degree of confidence considered is also 5 percent. The results are following:

Table 2. Granger Causality Test

\begin{tabular}{lcccc}
\hline \multirow{2}{*}{ Country } & \multicolumn{2}{c}{ FDI to Youth Employment } & \multicolumn{2}{c}{ Youth Employment to FDI } \\
\cline { 2 - 5 } & Chi2 & Prob & Chi2 & Prob \\
\hline Indonesia & 5,9798 & $0,050^{*}$ & 3,5804 & 0,167 \\
Malaysia & 5,4894 & $0,064^{*}$ & 0,6640 & 0,717 \\
Philippines & 22,459 & $0,000^{*}$ & 0,3807 & 0,827 \\
Singapore & 7,3817 & $0,025^{*}$ & 0,7601 & 0,648 \\
Thailand & 0,1355 & 0,934 & 18,087 & $0,000^{*}$ \\
\hline
\end{tabular}

Note: *significant in 5\% degree of confidence

Source: Data estimation (2020)

\section{FDI to Youth Employment}

The results in table 2 revealed that the relationship of FDI and youth employment differ among the members of ASEAN-5. In most countries: Indonesia, Malaysia, Philippines, and Singapore there is a relationship of FDI to youth employment. Host countries should not only be on the volume of inward FDI they received but also on which sectors they invested in and how this could bring benefit to the domestic economy in terms of employment creation (Ernst, 2005). Several researches have been done related to the impact of FDI on youth employment. Patel \& Choga (2018) and Ebaidalla (2014) investigated determinants of youth employment in developing countries. They found that FDI leads to youth employment. Another important study was conducted by Xaypanya et 
al (2015) which found that the factors affecting FDI could be different due to the development stages of the countries. For example on the comparison between ASEAN-3 countries, Laos, Cambodia, and Vietnam and the ASEAN-5 members, Indonesia, Malaysia, Philippines, Thailand, and Singapore in the research of Xaypanya et al (2015). Inflation was found to have a negative relationship on inward FDI in ASEAN-3, but in ASEAN-5, only the market size and infrastructure variables that found significant to enchant FDI.

\section{Youth Employment to FDI}

Table 2 shows that in Thailand, the relationship is between FDI and youth employment quite different from other ASEAN-5 countries. In Thailand, youth employment tends to raise FDI. The study of Asongu and Kodila-Tedika (2015) in BRICS BRICS (Brazil, Russia, India, China \& South Africa) and MINT (Mexico, Indonesia, Nigeria \& Turkey) countries shows that a growing youth population is seen as a positive demographic change that is favorable for FDI. In another study, Bhaumik and Banik (2006) found that reveals that the growing need for FDI and lack of enough technologyintensive workers, which in general young, is giving rise to the emerging competitive disadvantage of the Caribbean countries. So that it can be inferred that growing youth employment can be an advantage for a country to bring in FDI.

\section{Discussion}

Overall, as a part of ASEAN, the ASEAN-5 countries should benefit from proinvestment policies in this area that will be attractive to foreign or intra-region investors, for example, ASEAN Free Trade Area (AFTA) and ASEAN Investment Area (AIA) (Karim et al, 2019). As seen in table 3 and based on ASEAN Investment Report 2019, FDI flows to the ASEAN Member States in 2018 were varied. Three of five ASEAN-5 members (Indonesia, Singapore, and Thailand) received higher inflow, while the other two members (Malaysia and Philippines), however, experienced a lower level of inflows last year (ASEAN, 2019). With regard to youth employment, we need not only to look at the quantity or growth of FDI inflow but also to which sectors the FDI is being invested in.

In some literature (see Hasan \& Sasana, 2020; O'Higgins, 2010), there is one part of unemployment that is rarely discussed, namely the problem of youth unemployment. To date, many countries in the world have focused their views on adult unemployment (Hasan \& Sasana, 2020). Meanwhile, youth unemployment received less attention on the development agenda. Nowadays many countries in the world are facing a level of youth unemployment that is much higher compared to adult unemployment (aged 25-64). In total, the youth unemployment rate in 2010 was on average 13,1 percent around the world, while adult unemployment was far below that, around 4,8 percent (Hasan \& Sasana, 2020; O'Higgins, 2010). Thus in the next part, the discussion of the FDI - youth employment condition in each country will be presented. 
Jurnal Economia, 17(2), October 2021, 208-219

Table 3. FDI Inflow in ASEAN Countries (in US\$ billion)

\begin{tabular}{lcccc}
\hline Country & $\mathbf{2 0 1 5}$ & $\mathbf{2 0 1 6}$ & $\mathbf{2 0 1 7}$ & $\mathbf{2 0 1 8}$ \\
\hline Indonesia & 16,6 & 3,9 & 20,6 & 22,0 \\
Malaysia & 10,2 & 11,3 & 9,3 & 8,1 \\
Philippines & 5,6 & 8,3 & 10,3 & 9,8 \\
Singapore & 59,7 & 73,9 & 75,7 & 77,6 \\
Thailand & 8,9 & 2,8 & 8,0 & 13,2 \\
Brunei Darussalam & 0,2 & $-0,2$ & 0,5 & 0,5 \\
Cambodia & 1,7 & 2,3 & 2,7 & 3,1 \\
Laos & 1,1 & 1,1 & 1,7 & 1,3 \\
Myanmar & 2,8 & 3,0 & 4,0 & 3,6 \\
Vietnam & 11,8 & 12,6 & 14,1 & 15,5 \\
\hline
\end{tabular}

Source: The ASEAN Investment Report (2019)

\section{Indonesia}

From table 3, it can be inferred that after about a five times increase in inward FDI from 2016 to 2017, FDI in Indonesia rose further to US\$ 22 billion FDI inflow in 2018. This number goes to the manufacturing sector about US\$14 billion and the wholesale and retail trade sector, about US\$ 7 billion, and there is a contraction of -US\$ 6 billion of inward FDI in the mining sector. Intra-ASEAN investment still becomes a strong source of FDI inflow in Indonesia. In intra-ASEAN investor, Singapore is the largest contributor to Indonesia, valued for more than 48 percent of overall inflows. There is also growing inward FDI from the United States, China, and Japan, which contributed to the total rise in 2018.

If we observe which sectors are the main destinations for FDI, in Indonesia, manufacturing and wholesale and retail are still the main destinations for investment. In Indonesia, the manufacturing sector has not yet reached the advanced technology level which is very capital intensive, as well as the wholesale and retail sectors which require a lot of labour. Although the agricultural sector is still the sector with the largest employment in Indonesia, in recent years the manufacturing and service sectors have begun to outperform. The absorption of labour is indicated by the number of jobs that have been filled as reflected in a large number of working people. The absorption of the working population is caused by the demand for labour. Thus, in the case of Indonesia, it was found that the FDI relationship led to the absorption of young workers.

\section{Malaysia}

In Malaysia, there is a divestment of 13 percent to US\$ 8 billion in 2018, mainly caused by a 79 percent decline in inward FDI from Intra-ASEAN. Nevertheless, there were some betterment in the industrial sector. FDI in the Malaysian manufacturing sector grew by 2,7 times to US $\$ 4$ billion and more than doubled in the finance sector, accounted for more than US\$ 1 billion. Next, there is a significant divestment in the real estate sector, 
from US\$ 3 billion in 2017 to less than US\$ 1 billion in 2018, generate the decline in Malaysian inward FDI.

Specifically in Malaysia, the youth unemployment problem has existed since the 1980s. From 1982 to 1986, the unemployment rate in Malaysia rose sharply from 3 to 7 percent. At that time, the utilization of labour was low thus created high youth unemployment, which accounted for about three times the overall unemployment rate. Most of the unemployed were first-time job seekers with a lack of skill and experience.

Historically, the Malaysian basic sector was agriculture and the reduction in agricultural job creation occurred due to the deceleration performance. There was also a problem of low investment in this sector. It created a shortage of labour during the late 1940s to early 1980s. Along with it, the employment in tin mining, which is the main Malaysian mining commodity, shrunken around one-third from 80.100 labours in 1980 to 60.500 labours in 1985. Malaysian government responded to this by converting the mining land for agriculture. In this time FDI inward helps to lower the unemployment rate until 1997 when the global financial crisis happened. It affected the Malaysian economy in the rising of the unemployment rate to 3,2 percent in 1998. Over time, the wider usage of new technology and capital created higher labour productivity. This higher productivity coupled with higher value-added and higher employment in Malaysia, especially the youth. As Irpan et al (2016) found that since 2009, Malaysia tend to face a downward propensity on the inward FDI. Then this decrease in FDI lowering the employment rate significantly. Thus it is consistent with this paper's finding that in Malaysia FDI is important for youth job creation.

\section{Philippines}

In the Philippines, the FDI inflow was decline to $\$ 9,8$ billion in 2018 from US $\$ 10,3$ billion in the previous year. It was due to a significant divestment from the European Union, accounted one-sixth from US\$ 2 billion in 2017 to US\$ 340 million only in 2018. But there was also some increased investment from several countries, such as Hong Kong increased the FDI to Philippines by 2,5 times, while investment from Japan rose three times. Investment from China even increasing sharply by around seven times. The rising investment in finance, real estate, and other services sectors compensated the US\$ 1 billion downward of FDI in the manufacturing sector. FDI to the power industry sector also declined significantly from more than U\$ 1 billion in 2017 to U\$ 193 million in 2018.

Philippines continued to seek FDI to generate employment that leads to economic development for the country. Philippines government provides incentives and special investment ease to foreign investors. Noteworthy, some advantages offered by the Philippine government including free trade zones. They also claimed to have a large, educated, English-speaking, and considerable cost of the workforce (United States Government a, 2020). Therefore, the Philippines continues to improve its overall investment climate. The results, in 2019 Philippines reaching the rating to $\mathrm{BBB}+$ in investment. It is the country's highest credit rating since ever.

As of the beginning of 2020, the labour force reached 43 million workers, with the unemployment rate accounted 5,3 percent. Youth unemployment made up over 40 of percent from the total unemployment. More than 50 percent of employment was in the 
services sector, while in agriculture and industry sectors are 22,7 percent and 18,8 percent respectively. All of the sectors with high unemployment are sectors that can absorb a lot of labour. This is still related to the sharp decline in inward FDI around 2017-2018 from the EU, implied that inward FDI affecting youth in the case of Philippines.

\section{Singapore}

Next, overall FDI inflows to Singapore rose fairly in recent years. Singapore is the largest FDI host country in ASEAN, accounted US\$ 77,6 billion of inward FDI in 2018. This is the highest recorded level among other ASEAN-5 countries. This time, FDI inflows from the European Union increase by 4,7 times to US\$ 18 billion, Japanese investment increased by 32 percent to US $\$ 5$ billion and that from Korea increased more than three times to US\$2,3 billion. FDI from other economies also up forward, and they all compensated for the significant divestment from United States, valued US $\$ 28$ billion in 2017 to one-seventh or around US\$ 4 billion in 2018. Along with that, the United States MNEs that previously contributed to 37 percent of inward FDI to Singapore in 2017, but in 2018 the share declined sharply to 6 percent.

Basically, Singapore provides a very well climate for investment. This country has an open, trade-friendly economy, characterized by a conducive investment climate coupled with strong government regulations enforcement. Singapore has also recorded various kinds of achievements related to the investment climate. The World Bank's Doing Business 2020 report ranked Singapore as the world's second-best country to do business. Singapore was also ranked as the most competitive economy in the world in The Global Competitiveness Report 2019 by the World Economic Forum. Besides that Singapore government be approved to have very high integrity and actively enforces anti-corruption laws, so Singapore successfully ranks as the least corrupt country in Asia and one of the least corrupt country globally. Transparency International's 2018 Corruption Perception Index ranked Singapore in the fourth place as a country with the lowest corruption rate (United States Government b, 2020).

In the middle of 2019, accounted 3,7 million workers in Singapore's labour market. This number includes about 1,4 million foreigners basic skilled or semi-skilled workers. This shows that inward FDI not only creates employment for local people but also foreigners in Singapore. But since 2011, the government has introduced a policy to reduced dependence on foreign labour. Since Singapore still faces the problem of youth unemployment. In 2019, thereabout 8,43 percent of the unemployed youth in the labour force. It was calculated that in 2018 approximately 841 thousand people in the labour force hold a degree. In Singapore, most youths work in the informal sector. The fresh graduates in Singapore are usually either unemployed, working part-time, or in temporary employment (Hirschmann, 2020). Generally, there has been a well-declining youth unemployment rate since 2005, accounted 14,7 percent and 10,3 percent in 2013 (ILO, 2017). This is in line with the study of Hasan \& Sasana (2020) that examined the determinants of the youth unemployment rate in ASEAN. It found that FDI significantly correlated to youth unemployment in a negative direction, implied that the higher FDI inflow, the higher youth employment. 


\section{Thailand}

Lastly, in Thailand, a quite different relationship was found between FDI and youth employment, where youth employment is what affects inward FDI. In 2018, Thailand experienced a 65 percent growth in inward FDI to $\$ 13$ billion. This is the highest growth among other countries at the moment. It makes a 186 percent FDI increase from 2016 to 2017. The rise was contributed by a quite significant increase in manufacturing inward FDI, valued at US\$ 2 billion in 2017 then more than doubled to US\$5 billion in 2018. The upward trend of inward FDI in finance, real estate, wholesale and retail trade also helps to push the inflow. Manufacturing and the two other main sectors in Thailand, namely the finance and real estate sector contributed more than 88 percent in the $2018 \mathrm{~s}$ inward FDI.

In the middle of 2020, the workforce size in Thailand was 38,05 million people but this country accounted for a quite low unemployment rate of 1,9 percent. Each year about 800.000 people enter the labour market. In Thailand many standard labour practices are applied, for example, mandatory severance payment and overtime wages. The recent minimum wage in Thailand is around 313 baht per day and the Thailand Board of Investment (BOI) claims that their workforce is among the most efficient in the labour cost, with the labour reputation of well diligence and adaptability (Thailand Board of Investment, 2020). This can be the basis that the employment conditions in Thailand are indeed favourable for investment due to the efficient labour cost.

\section{CONCLUSION}

Since the aim of this study is to examine the link between FDI and youth employment in ASEAN-5 countries, it is found that in Indonesia, Malaysia, Philippines, and Singapore the FDI inflow is a driver of youth employment, while contrarily in Thailand the youth employment is found to affect FDI inflow. The favorable, efficient labour cost is one of the main pull factors. To manifest youth employment enforcement, countries in ASEAN5 need integrated youth employment policies, involving different stakeholders and ranging on the various level of government, to formal and informal education institutions. There should be youth-specific regulations among overall employment policies in the country.

\section{REFERENCES}

Adam P. B., Zurek, M., (2011), Foreign Direct Investment and Unemployment: VAR Analysis for Poland in the Years 1995-2009, European Research Studies, Volume XIV, Issue (1).

Bakkalc1, A. C. and N. Argin (2013), Internalization of Foreign Trade in the Context of Labour Market Induced by Foreign Investment, Journal of Labour Relations, Vol. 4, Number 1, pp. 71-97.

Ebaidalla, E. M. (2014, November). Effect of ICTs on youth unemployment in Sub Saharan Africa: A panel data analysis. In A paper prepared for African Economic Conference on "Knowledge and Innovation for Africa's Transformation", Abidjan, Cote d'Ivoire, $1 s t-3 r d$. 
Erdal, F., \& Tatoglu, E. (2002). Locational determinants of foreign direct investment in an emerging market economy: evidence from Tukey. Multinational business review, 10, 21 27.

Ernst, Crhistoph. (2005). The FDI - employment link in a globalizing world: The case of Argentina, Brazil and Mexico. Employment Analysis Unit Employment Strategy Department. ILO.

Goel, N. (2020). Repercussion of FDI on employment generation in Indian retail: a statistical analysis. International Journal of Business and Globalisation, 25(4), 405-418.

Hasan, Zainul. and Sasana, Hadi. (2020). Determinants Of Youth Unemployment Rate In ASEAN. International Journal Of Scientific \& Technology Research Vol. 9 (3). pp 66876691.

Hirschmann, R. (2020). Youth unemployment rate in Singapore 2011-2020. Retrieved from https://www.statista.com/statistics/708329/singapore-youth-unemployment-rate/ at December $10^{\text {th }}, 2020$.

ILO (2011). Global Employment Trends for Youth, Geneva: International Labour Organisation.

ILO. (2017). Youth Employment Policy Summary Singapore. Geneva: International Labour Organisation.

ILO. (2020), Global Employment Trends for Youth 2020: Technology and the Future of Jobs. Geneva: International Labour Organisation.

Irpan, H. M., Saad, R. M., Nor, A. H. S. M., Noor, A. H. M., \& Ibrahim, N. (2016). Impact of foreign direct investment on the unemployment rate in Malaysia. In Joumal of Physics: Conference Series (Vol. 710, No. 1, p. 012028).

Jibir, A., \& Abdu, M. (2017, January). Foreign Direct Investment - Growth Nexus: The Case of Nigeria. European Scientific Journal, 13(1), 304-318.

Karim, B. A., Karim, Z. A., \& Nasharuddin, M. N. (2019). Corruption and Foreign Direct Investment (FDI) in ASEAN-5: A panel evidence. Economics and Finance in Indonesia, 64(2), 145-156.

Karlsson, S., Lundin, N., Sjöholm, F., \& He, P. (2007). FDI and job creation in China (No. 723). IFN Working Paper.

Lipsey, Robert E. (2006), Measuring the Impacts of FDI in Central and Eastern Europe. National Bureau of Economic Research Working Paper No. 12808.

Mkombe, D., Tufa, A. H., Alene, A. D., Manda, J., Feleke, S., Abdoulaye, T., \& Manyong, V. (2020). The effects of foreign direct investment on youth unemployment in the Southern African Development Community. Development Southern Africa, 1-16.

Msigwa, R., \& Kipesha, E. F. (2013). Determinants of youth unemployment in developing countries: Evidences from Tanzania. Journal of Economics and Sustainable Development Vol.4, No.14, 2013.

O'Higgins, N. (2010) The Impact of the Economic and Financial Crisis on Youth Employment: Measures for Labour Market Recovery in the European Union, Canada and the United States., ILO Working Papers.

Parcon, H. (2008). Labor market flexibility as a determinant of FDI inflows. University of Hawaii at Manoa, Department of Economics, Working Papers, 08-07. 
Patel, Dipali Pravin Chhaganlal \& Choga, Ireen. (2018). Determinants Of Youth Unemployment In South Africa. 9th Economics \& Finance Conference, London 22 May 2018.

Pieters, Janneke. (2013). Youth Employment in Developing Countries. IZA Research Report No. 58, issue October 2013.

Strat, V. A., Davidescu, A., \& Paul, A. M. (2015). FDI and the unemployment-a causality analysis for the latest EU members. Procedia economics and finance, 23(2015), 635-643.

Thailand Board of Investment. (2020). Thailand in Brief. Retrieved from https://www.boi.go.th/index.php?page=demographic at December 10 $0^{\text {th }}, 2020$.

Tsaurai, K. (2018). Exploring the employment effect of FDI in BRICS: Does conditionalities matter?. Acta Universitatis Danubius. Economica, 14(3), 86-103.

United States Government a. (2020). 2020 Investment Climate Statements: Philippines. Retrieved from https://www.state.gov/reports/2020-investment-climatestatements/philippines/ on December $9^{\text {th }}, 2020$.

United States Government b. (2020). 2020 Investment Climate Statements: Singapore. Retrieved from https://www.state.gov/reports/2020-investment-climatestatements/singapore/on December $9^{\text {th }}, 2020$.

Xaypanya, P, Rangkakulnuwat, P, \& Paweenawat, SW 2015, The determinants of foreign direct investment in ASEAN: The first differencing panel data analysis. International Journal of Social Economics, 42(3), pp.239-250

Yayli, S. and M. K. Deger (2012), The Relationships Between Foreign Direct Investments and Employment: Dynamic Panel Data Causality Analysis on Developing Countries (1991-2008), Finans, Politik ve Ekonomik Yorumlar, 49 (568), pp. 43-51. 